\title{
From the Editor of Sexuality and Disability: The Year 2021...A Pause for Reflection
}

\author{
Sigmund Hough ${ }^{1}$
}

Accepted: 14 October 2021 / Published online: 1 November 2021

(C) The Author(s), under exclusive licence to Springer Science+Business Media, LLC, part of Springer Nature 2021

The journal, Sexuality and Disability, continues to be a professional home and a place of professional rejuvenation for study and advancement. Many have followed the journal since the 1970's. If you are new to the journal, we always give to you a "BIG WELCOME" and invite you to participate as a reader, author, academician, clinician, educator, service provider, researcher, advocate, or person seeking information. Over the years of contribution to the literature on sexuality and disability healthcare, we have been a part of the growth, understanding, and advocacy. Most important, we continue to be a part of the change in how we look and examine the topic, the needs, and the response in terms of best practiceevidence based approaches. With the intelligence, experience, motivation, and supportive dedication from our authors, readership, international peer reviewers and international editorial board members, and resources combined with valuable guidance from the Springer Staff; our journal's mission continues to be meaningful and productive. This international effort continues as a strength in the field of sexuality and disability.

Since 1978, Sexuality and Disability has pushed for pragmatic knowledge to have impact on education, research, and practice. Sexuality and Disability makes available original impact articles addressing the mental health and medical healthcare aspects of sexuality in relation to rehabilitation, hospital, academic, and community settings, publishing up-to-date articles, invited case studies, clinical practice reports, reviews, featured articles, historical articles, special grand rounds topics, brief research reports, and survey data reports. Value benefit is provided to authors through worldwide electronic exposure and professional access, while readership gains knowledge from scholarly contributions which advance the field through research, evidence-based, best-practice and educational articles. Individual contributions from the local and international community delivers a wealth of information with broad perspectives on the topic of sexuality and disability.

As the year 2021 comes to a close, we reflect upon the world events and individual experiences. Peace, health, safety and enjoyment in the year ahead for all.

Thank you for joining our professional efforts.

Sigmund Hough

Sigmund_Hough@hms.harvard.edu

1 Beverly, MA 01915, USA 
Publisher's Note Springer Nature remains neutral with regard to jurisdictional claims in published maps and institutional affiliations. 